\title{
A HISTORY OF THE NATIONAL CONFERENCE OF COMMISSIONERS ON UNIFORM STATE LAWS
}

\author{
Allison Dunham*
}

I

\section{Methods and Policy Objectives}

Wherever there is a problem regarded as common to two or more areas governed by different legislatures, a question inevitably arises as to how the law of the areas may be made uniform whenever it is desirable to do so. There appear to be three methods of obtaining the uniformity assumed to be desirable: ( $I$ ) by voluntary action of the two law-making bodies adopting identical laws; (2) by agreement negotiated by a representative of the two governments and adopted by the appropriate legislative bodies; (3) by direction of a superior law-making body capable of compelling other law-making bodies to desist from having separate, distinct, and different laws.

The first, or voluntary method, is always available without regard to the structure of the governments. The only requisite for this method is that both governments have a power to legislate on the subject involved. Thus, within a nation, or a state of a federal system having many local self-governing bodies, such as cities and villages, it is possible for two or more municipal governments voluntarily to adopt an identical law on any subject over which they have legislative power; it is equally possible for two or more states within a federal system voluntarily to adopt an identical law; and it is possible for two or more national states voluntarily to adopt an identical law.

The method of obtaining uniformity by direction depends on the structure of government of the two areas involved. Thus, in most parts of the world it is possible for a central government having power over the municipal governments to obtain the desired uniformity by enacting a law of its own which is supreme over the laws of these lesser units of government. Within a federal system this method of obtaining uniformity is also available wherever the constituent states have, with respect to a subject, concurrent power with the national government. Thus, in the United States it is possible to obtain uniformity in many matters simply by Congress enacting a law which under the supremacy clause of the United States Constitution supersedes state law. If there is no government having supreme or superior power over the other legislative bodies involved, this method, uniformity by direction, is not an available choice. Thus, in the international world where

- Professor of Law, University of Chicago; Executive Director, National Conference of Commissioners on Uniform State Laws. 
uniformity of law is desirable among sovereign nations, it is not possible to obtain uniformity by direction. Here, the choices available are the first or the second methods mentioned above.

Uniformity by agreement, the second method mentioned above, requires consideration of certain additional elements not involved in the first and the third methods. An agreement differs from the voluntary action method on an assumption that there is some sanction for deviation from the agreement, or that there is some decision-making body capable of making interpretations that are binding on the courts of the two separate jurisdictions. If municipal governments in a unitary state and for state governments in a federal system are to use the agreement method, it is necessary that they have power to make agreements that are binding on successor law-making bodies. Thus, in the United States Constitution there is express recognition of the method of agreement between the states, but only with the consent of Congress. In the United States Constitution the method of agreement is called an interstate compact. If the agreement is made, and if Congress has approved or authorized it, then there is in the United States a judicial system capable of enforcing the agreement against a state which contrary to the agreement deviates from its terms. ${ }^{1}$ Among sovereign nations there is little question of the power to make an agreement binding on successor legislative bodies, but there is always a problem of preventing deviation from the agreement. If there is an international court capable of interpreting the agreement, i.e., a treaty or a convention, there is a method of enforcing the agreement, and if there is no court system available sometimes the agreement itself may contain a procedure creating a deciding body for particular disputes.

Each of the three methods involves the law-making process. This process may be utilized on an ad hoc basis, or there may be established and permanent institutions continually seeking uniformity by one or more of the methods proposed. These organizations may be established on a subject basis, such as an international organization seeking uniformity of the rules concerning air traffic, ${ }^{2}$ or they may be organized on a more general basis. Thus, in the federal states, such as Canada and the United States, there is an established organization promoting uniformity of law by voluntary action. The National Conference of Commissioners on Uniform State Laws, the national organization of Commissioners appointed by the Governors of the states of the United States, is a perpetual body seeking uniformity of law by voluntary state action. The Canadian Commissioners on Uniform Laws is a similar organization. In the international field there are also organizations dedicated to obtaining uniformity of law. The Hague Conference, organized in

${ }^{2}$ M.C. Hinderlider v. La Plata River and Cherry Creek Ditch Co., 304 U.S. 92 (x938).

${ }^{2}$ E.g., the International Civil Aviation Organization and the Air Transport Association of America. See generally Sand, The International Unification of Air Law, infra, pp. 400-24. 
$1893,{ }^{3}$ and the Rome Institute, organized in $1926,{ }^{4}$ are international organizations dedicated to seeking uniformity of law among nations. These two organizations use as their primary vehicle for obtaining uniformity the agreement (or convention) method. The Commissioners on Uniform Laws have occasionally considered the agreement method, and the international organizations have occasionally considered the voluntary method, even though their primary purpose is, in the case of the Commissioners, the voluntary method, and, in the case of the two international organizations, the convention method. In order to compare the two methods it may be useful to describe the history of the National Conference of Commissioners on Uniform State Laws. Before so doing, however, it seems appropriate to consider some of the arguments advanced both in a federal system and internationally in favor of uniformity of law.

The most commonly advanced argument for uniformity is "necessity" in the economic or social sense. Thus, both the state legislation creating the commissions on uniform state laws in the United States and the Constitution of the National Conference of such Commissioners emphasize the duty of the Commissioners to draft uniform laws where uniformity is "necessary." The same emphasis on necessity appears in the Constitution of the Hague Conference and the Rome Institute. The literature concerning the two organizations also emphasizes economic necessity, and much of the effort of the two organizations has been directed to laws involving economic matters. The National Conference was organized in r892 in part to obtain uniformity in such commercial matters as negotiable instruments and sales, and its most recent major achievement, the Uniform Commercial Code, is illustrative of the "necessity" for uniformity in commercial matters where a transaction involves the jurisdiction of more than one legislative body. The Rome Institute and the Hague Conference have likewise worked in the area of "international sales" and "international bills of exchange."

A second argument frequently advanced for uniformity has not been so heavily emphasized in the United States. This is the "necessity" of maintaining symmetry or uniformity of concept or theory of law. In the British Commonwealth, for example, some of the Commonwealth legislatures are urged to adopt a particular law reform statute in order to keep "the" common law of the members of the Commonwealth similar to that of the mother of the common law system. Until

\footnotetext{
"The full title is "The Hague Conference on Private International Law," and its charter directs it to "work on the progressive unification of the rules of private international law."

"The full title is the "International Institute for the Unification of Private Law," and its stated objective is to examine "ways of harmonizing and coordinating the private laws of states and groups of states." See generally, American Bar Foundation, Report of the A.B.A. Special Commitiee on INternational Unification of Private LAw (I96r), and Nadelmann, The United States Joins the Hague Conference on Private International Law, infra, pp. 291-325.

S See Model Act to Provide for the Creation of a Commission on Uniform State Laws, the Appointment of Commissioners Thereto, and Making an Appropriation for the Same, I944, $\$ 2$, Constitution of the National Conference of Commissioners on Uniform State Laws, $\$ 2$, in 1964 HANDBoor of THE National Conference of Commissioners on Unjform Laws 3 Io [hereinafter cited as Handbook].
} 
nations with a common law tradition joined the Hague Conference and the Rome Institute, this theoretical or conceptual reason for uniformity heavily influenced the work of these two organizations. The necessity of keeping uniformity of theory in the mother "Roman Law" or mother "Napoleonic Code" was emphasized in legal literature, and it was said to be desirable for countries having this common background to maintain uniformity in application of theory.

There is also a more abstract variant of this second argument in favor of uniformity. Theoreticians sometimes deduce from an analysis of legal theories that the solution of a particular problem "ought" to be such and such, and urge that law should be changed in order to conform with this theoretical "oughtness." Since theory has produced "the" solution, all states ought to adopt it and therefore have uniform law. Thus, argument in favor of uniformity is sometimes more pronounced in organizations where the delegates are frequently academicians from a system where theory tends to dominate the work of the academic community. In the United States, where the Commissioners on Uniform State Laws have been drawn from the judiciary, the practicing bar, and from the academic community, this justification for uniformity has not been heavily emphasized.

Another argument for uniformity, which has not been used much in the literature concerning the organized groups seeking uniformity, but which has been advanced frequently in the United States generally, is the desirability of obtaining uniformity of culture and attitude. It is now known that law does perform an educative function, and those desiring more uniformity of attitude and ethical conduct among areas of the world sometimes promote uniformity for this reason. The National Conference of Commissioners on Uniform State Laws has been urged from time to time to be more active in the field of divorce and marriage in order to promote uniformity of culture and attitude on these subjects throughout the United States, as well as promoting uniformity where uniformity is "necessary."

At the time the National Conference of Commissioners on Uniform State Laws was organized in 1892 , the conception of its role was primarily similar to that of the two international organizations previously referred to. The National Conference was conceived as necessary for the attainment of uniformity where uniformity could not be obtained by direction. In the Proceedings of the American Bar Association, which was primarily responsible for the creation of the Commissioners on Uniform State Laws, a recurring strong argument for the creation of the organization was the legal fact that the areas of concern were thought to be beyond the scope of congressional power, so that uniformity could not be obtained by congressional action. Thus, in an 1890 report of the American Bar Association it was stated $:^{6}$

The adoption of a commercial code by Congress, such as was suggested by a committee of this Association a few years ago, would be only a partial remedy. Many

\footnotetext{
'See I3 A.B.A. ReP. 262 (1890). (Emphasis added.)
} 
negotiable notes and bills passed from the hands of citizens in one state into those of another, upon which it is clearly not within the constitutional power of Congress to legislate. Hundreds of thousands made in one state and discounted in the banks of that state are rediscounted in the banks of other states every year. The regulation by Congress of such paper as that can scarcely be claimed under the power to regulate interstate commerce.

Some of the original enabling acts creating state Commissioners on Uniform State Laws stated the same idea by expressing the duties of the Commissioners to be to draft uniform laws in areas "where Congress had no jurisdiction."7

The National Conference was organized within a very limited concept of the United States Constitution. The very limited interpretation of the power of Congress to regulate interstate commerce, which is indicated in the passage quoted above, meant that uniformity, where necessary, could be achieved only by some method other than the exercise of congressional power. At the same time, the Conference, in drafting legislation for voluntary state action, was required to take cognizance of another very serious constitutional doctrine-the rather broad concept of "negative implication" of the commerce clause even where Congress had not legislated. Thus, in his report of $\mathrm{IgII}$, after indicating that uniformity of law was desirable in the areas of incorporation, pure food and drugs, and warehouse receipts, the president of the Conference acknowledged that in some parts of these subjects uniformity could be secured only through congressional action. ${ }^{8}$

As the limiting effect of the federal constitution on congressional power has steadily declined through judicial interpretation, and as the "negative implication" effect of the federal constitution on state power has similarly declined, the work of the Conference, particularly as reflected in the reports of the president, does not indicate any major attempt to work out a theory as to when uniformity of law should be obtained by voluntary action and when it should be obtained by direction. From the very beginning, including the early reports of the American Bar Association, it has been a theme that uniformity of law by voluntary state action was a means of removing any excuse for the federal government to absorb powers thought to belong rightfully to the states. As the power of the federal government has expanded, the presidents' reports of the Conference have more often emphasized this "states rights" objective. Occasionally, a president of the Conference has suggested that in areas where uniformity is desirable and where there is congressional power, perhaps exclusive congressional power to impose uniformity by direction, the National Conference should assist Congress by drafting such uniform legislation. However, this approach to uniformity has been exceedingly rare in the reports of the presidents, in part because of the emphasis on preserving the autonomy of the states, and in part because the statutory power of the Commissioners on Uniform

\footnotetext{
${ }^{7}$ See, for example, the present act of Massachusetts, Axw. LAws Mass. c. 6, $\$ 27$ (I96I). See Model Act of 1908 to the same effect, I908 HANDBOoK 73 .

${ }^{8}$ I9II HANDBOOK II5.
} 
State Laws has been interpreted as being limited to obtaining uniformity by voluntary state action. In a sense, the failure of the Conference to make a serious attempt to limit or define the scope of its work in relation to congressional power is a reflection of another policy of the Conference. The emphasis on "necessity" as the major reason for uniformity has pushed the Conference into expressing little concern for theory or consistency of concept, and it has rather emphasized solution to particularly pressing problems.

\section{II}

\section{The Relation of National Conference to Federal Action}

Although the Conference has conceived its role to be that of obtaining uniformity by voluntary state action, it has throughout its history been concerned with the two other methods of obtaining uniformity-by direction and by agreement. In the early rgoos, when Congress had under consideration a pure food and drug act, the Conference became interested in the same subject, and eventually recommended the adoption of the federal act by the states to cover the areas where manufactured drugs did not cross state lines.' Another reason for uniformity is suggested by this episode: to the extent that a federal act does not completely cover a particular situation, there may be a need for a uniform state law in order to make that part of the activity which is unregulated by federal law subject to the same regulation on the state level. But the extension of the power of Congress to transactions which "affect" interstate commerce suggests that in many areas, if Congress were so inclined, it could obtain this type of uniformity by direction, so that voluntary state action is not the sole method for coordinating the law.

Congress has frequently passed legislation covering a particular subject, but has based the federal legislation in whole or in part on the existence of a particular state law, and at times it has passed legislation which becomes inoperative if the states have a particular kind of law. The role of the National Conference in connection with federal tax liens is illustrative of this relationship of the National Conference to uniformity by direction. Although federal tax liens are inherently prior to any other type of lien, Congress in the rgzos determined that the priority of federal tax liens should depend, as does the priority of non-federal liens, on a recordation system, and has provided that federal tax liens should have priority only if they were publicly recorded or filed. It was, of course, theoretically possible for Congress to have provided a federal system of recordation for such liens, and the Federal Tax Lien Act did provide that in order to establish priority, liens could be filed in the office of the clerk of the Federal District Court. ${ }^{10}$ Congress, however, has also provided an alternative: if state legislation concerning priority of liens meets certain requirements, then the priority of a federal tax lien would be determined

Igo8 HandBook $15 \mathrm{x}$.

${ }^{10}$ INT. REv. CODE OF I954, $\$ \$ 632 \mathrm{I}-6326$ (tax lien). 
only by filing in an office set up by the states in accordance with a state procedure. The Uniform Federal Tax Lien Registration Act of 1926 was the response of the National Conference to this invitation, and the Conference is currently revising its tax lien registration act in order to keep it abreast of contemplated developments by Congress in the same field. Thus, another incentive for uniformity may be the decision of the central government to preserve power within the states if certain conditions are met. The Civil Rights Act of 1964 is another illustration of Congress staying its power where there is an applicable state act being enforced; ${ }^{11}$ and the National Conference has under consideration a project for a uniform state civil rights act based on the 1964 Act so that state law rather than federal law may operate in this area. ${ }^{12}$

Another role of the National Conference in relation to the federal government, and one in which it may become increasingly involved, is the role of advising Congress on the desirability of certain kinds of uniformity. Early in its existence, the Conference was asked to advise the United States as to the position this country should take as to an international convention establishing uniformity of law concerning certain types of negotiable instruments. ${ }^{13}$ Since the Conference had at that time recently drafted its own Uniform Negotiable Instrument Act, and since the convention proposed different rules from the Uniform Negotiable Instrument Act, the Conference advised the Secretary of State not to recommend to Congress the adoption of the convention.

With the rapid increase in the types and magnitude of international commercial and social transactions, it is likely that the "necessity" for international uniformity of law will increase. The Conference has been cognizant of this type of necessity for many years. In its first consideration of the Uniform Commercial Code in the I940s, emphasis was put on the "necessity" for uniformity arising from the fact that foreign merchants dealing with businesses in the United States needed a uniform law in the United States as a reliable reference. There is, of course, a reciprocal interest of American businesses engaged in transactions in other countries. Since 1957, the Conference has been concerned with international uniformity, and it has had observers at the meetings of the Hague Conference and the Rome Institute where international uniform laws were being drafted. The Conference joined other organizations, such as the American Bar Association, in urging the United States to become a member of these two international organizations, which it did in $1963 .^{14}$ While it has been a much debated question, over time, whether the treaty-making power, which is a monopoly of the federal government, could be used to impose upon the states law on a subject otherwise reserved to the states, the facts indicate

\footnotetext{
${ }^{11} 78$ Stat. 241,42 U.S.C. $\$ 2000 a-3$ (c) $(1964)$.

12 See Tentative Draft No. I, Uniform Civil Rights Act.

${ }^{13}$ I9II HANDBOOK III-I3.

1477 Stat. 775,22 U.S.C. $\$ 269 g$ (Supp. V, 1963).
} 
that many of the subjects which are of concern to the international organizations drafting internationally uniform laws, have traditionally been left to the states in the United States. This has created a peculiar difficulty for both the National Conference and the Secretary of State. Even though international uniformity is desirable, it is politically difficult to muster support where no representatives of state governments actively participated in the drafting of legislation. Thus, it would be politically difficult for the National Conference to adopt automatically, and without participation in the drafting process, laws proposed by the Hague Conference or the Rome Institute.

From the Secretary of State's point of view, there is a similar difficulty. Most conventions to which the United States is considering becoming a party concern subjects as to which there is considerable expertise and interest in the departments of the federal government. Thus, on international water laws, the Department of Interior has available experts and knowledge helpful to the negotiation of treaties. The subjects typically before the Hague Conference and the Rome Institute, however, have been conventionally left to the states as far as domestic law is concerned, and Congress has not as yet made available to the Secretary of State the resources to undertake the research necessary for drafting internationally uniform laws in these topics. During the first year of membership in the Hague Conference and the Rome Institution, an experimental procedure for United States participation has been worked out which may ultimately satisfy the problems arising in a federal system in securing uniformity of law where the necessity for uniformity is international in character. The Secretary of State has established a National Advisory Committee drawn from the membership of organizations such as the American Bar Association and the National Conference of Commissioners on Uniform State Laws, to advise him on subjects where international uniformity of private law is desirable, and has designated as official U.S. delegates to the drafting sessions of the two international organizations Commissioners with long experience in drafting uniform laws on the same subject domestically.

The National Conference has created a new committee, the Committee on International Uniformity of Private Law, to be responsible for the role of the National Conference in drafting the internationally uniform laws. This Committee will supervise the research necessary for United States participation, and prepare for consideration of the National Conference recommendations as to the position to be taken by the United States on the particular subjects on the agenda of the two organizations. It is hoped that by the use of this procedure, also involving the regular procedure of the National Conference of deliberation on draft acts by all of the Commissioners, that a broad base of advice for the United States will be obtained. Experts on comparative law in the United States are, of course, also actively involved in the consideration of these topics. Through the deliberations of 
the National Conference and of other groups, it is expected that the Secretary of State will be advised as to position which should be taken on particular drafts, and after a convention has been agreed upon, advice will be given as to whether the Secretary of State should seek ratification of the convention by the United States. ${ }^{15}$

The remaining difficulty with this procedure is the method of financing the necessary research for United States participation. It is not so easy for the Secretary of State to call upon other departments of the federal government for background material on the subjects being considered by the Hague Conference or the Rome Institute, because these subjects do not customarily enter into the operations of the federal government. They have been, in fact, left to the states. The National Conference has obtained a grant from the Ford Foundation to help finance the necessary research on topics likely to come before the two international organizations during the next few years. While the federal government has received an appropriation for the expenses of membership in the Rome Institute and the Hague Conference, and for the expenses of the delegates in attending the meetings of the two organizations, Congress has not yet appropriated funds for research activities. Success during the early years may persuade Congress to help finance the research which will be necessary for long-range participation in obtaining internationally uniform laws. Whether United States commitment to the internationally uniform law agreed upon by an international conference will come through congressional action to implement the ratified convention, or through the recommendation of the federal government that the states adopt as their own substantive law the rules agreed upon, is not yet clear. Since the substantive rules, if they are good ones for international transactions, are also likely to be good for domestic matters, it would seem that the preferable first choice should be that of securing the particular substantive rule as part of the domestic law of the states.

There are other reasons for adopting this approach rather than uniformity by direction, and the relationship of the Conference to the federal government with respect to other subjects is illustrative of this problem. The Conference has been faced from time to time with the problem of a proposed federal act on the very narrow aspect of a much larger subject. Thus, in the I940s, when first consideration of the Uniform Commercial Code was commenced, there were proposals for a federal act covering interstate sales only. The Conference approach to the subject of commercial law was much more comprehensive than the federal proposal, since it encompassed not only interstate sales but all sales, and extended to many other transactions of a largely interstate and international nature, such as negotiable instruments, security transactions, and secured credit transactions. For various reasons, the federal government did not adopt a sales law applicable to interstate

25 The National Conference has on its 1965 agenda consideration of a convention on the Service abroad of Judicial and Extrajudicial Documents in Civil or Commercial Matters, approved at the Tenth Session of the Hague Conference in October 1964 . 
sales, and the Conference proceeded with its more comprehensive treatment in the Uniform Commercial Code.

More recently, the Conference has participated in proposed federal action through the testimony of its president concerning Senate Bill $75^{\circ}$ in the Eighty-eighth Congress, involving one aspect of consumer credit-the method of disclosing the finance charge or cost of credit to the borrower or buyer. The Conference urged the Congress not to adopt a federal law dealing with this narrow aspect of consumer credit, because the Conference had under way a much broader and more comprehensive act on the same subject, covering all matters from advertising of consumer credit through the form of the contract, the maximum amount of finance charge, and the collection process. Not only would it be difficult to draft a comprehensive state law around a previously adopted federal position on one aspect of the subject, but the public relations campaign involved in securing national legislation on such a matter would also tend to interfere with obtaining uniformity by voluntary state action on the much broader subject. Once there is a law, there is tendency to assume that the whole subject matter has been dealt with.

Beginning with the second twenty-five years of its history, the Conference has been concerned with interstate compacts, i.e., the method of obtaining uniformity by agreement among the states. In 1915, it was proposed to the National Conference that it should prepare an enabling bill for congressional adoption permitting more general use of agreements between the several states of the United States. An elaborate committee report was filed with the National Conference in 1921. ${ }^{10}$ The significance of this report is its recognition that an interstate compact was merely another method of obtaining uniformity of law. The report attempted to indicate areas where this method had an advantage over the voluntary method. It recommended to the Conference that the interstate compact method was preferable for subjects requiring state cooperation in administrative control, such as one state supervising parolees and probationers from another state. The Committee also at that time recommended use of interstate compacts as a method of obtaining international uniformity. Its proposal was that Congress should authorize the states through the interstate compact technique to negotiate directly with foreign nations concerning uniformity of private law. The report emphasized the fact that the United States was a "self-inflicted cripple" in matters concerning international uniformity of private law because while Congress had exclusive treaty-making power, its jurisdiction over substantive subjects did not cover all of the areas where international uniformity of law was desirable. It further emphasized the absence of congressional power under our Constitution to adopt laws on some of these subjects. The Committee thought in $192 \mathrm{I}$ that the only solution to this problem was the direct participation of the states in international conferences on subjects for international uniformity of legislation. It proposed that Congress give its

\footnotetext{
${ }^{10}$ Sec I92I HANDBOOK 299-367.
} 
consent in advance to a state making a compact with one or more foreign powers upon a specified subject of law, such as warehouse receipts used in international transactions. Since 192I, however, other methods, such as the one currently in use and described above, have been adopted to permit United States participation in drafting of internationally uniform law.

Where the subject matter was purely domestic and did not involve much in the way of administrative action within the states, the Committee attempted to compare the then historic method of the National Conference, i.e., uniformity by voluntary adoption of identical law, with the compact method. The Committee saw very little advantage in the compact method over the voluntary method, because it believed that most state legislatures in using a compact on subjects as, e.g., sales, would impose as a "reservation" to the compact a time limitation on the duration of the obligation to have identical law. It also saw constitutional difficulty in the attempts of legislatures to bind their successors as to the content of legislation for any period of time. Treating these two-time questions as given, it seemed to the Committee that there was no great advantage of the compact method aver the voluntary method whereby each state adopted textually uniform laws.

Similar problems as to the performance of a uniform solution arise when the effort is to obtain uniformity of law internationally. The Hague Conference and the Rome Institute have operated primarily through the system of uniformity by agreement, and the United States delegates have presented to these organizations proposals that for some subjects, at least, they should consider the "uniform law" approach rather than the convention approach. What is the difference between obtaining uniformity by agreement and obtaining uniformity by voluntarily adopting an identical law? There is, of course, the difference in permanence of the uniformity. Uniformity obtained by voluntary action can, with equal voluntariness, be changed unilaterally by any legislature at any time, whereas under the agreement method, presumably there is some period of time during which the law could not be charged without the violation of binding commitments. The I92I report of the Committee of the National Conference indicated a belief that if the compact method were used extensively, legislatures would tend to impose time limitations on the duration of the agreement. If that is true, this difference becomes of less significance.

If we compare the method of operation of the National Conference with that of the Hague Conference, the difference between the two methods seems primarily one of attitude toward the new uniform law and the freedom of the officials involved in drafting or agreeing to the uniform law. In the international field, if the agreement method is used, the persons charged with negotiating the agreement and empowered to agree to a particular provision of law are much more controlled by the government which they represent than are the experts charged with the 
duty of drafting an acceptable uniform law. Whether this difference is inherent in the two methods or merely has grown up in practice is hard to determine. It would appear, however, that at least in the international field, uniformity by agreement tends to induce the national negotiations to seek to minimize deviation from the existing local law of their principals, whereas the officials empowered to draft a uniform law to be adopted by voluntary method have, in practice, sought the "best possible" solution without regard to the deviation from existing law. The tendency in the systems obtaining uniformity by agreement seems to have been to harmonize the rules of the participating states rather than that of seeking the ideal solution. Where uniformity has been sought by voluntary action the Commissioners on Uniform State Laws have not felt obligated to the law of their state, but rather have felt duty-bound to seek the best solution. In part, this may have been due to the origins of the National Conference in the law reform activities of the organized bar rather than the official representative conferences of the member states.

It would appear that the differences between the Hague Conference and the National Conference do not inhere in the methods of obtaining uniformity used by the two organizations; rather, these differences seem to have resulted from the conception of the role of the delegates and from the use of the organized bar in the drafting operation. The broad mixture among the Commissioners of Uniform State Laws of Commissioners with judicial, academic, and private practice backgrounds would appear to be a stronger basis for the difference between the two organizations than is the official nature of the activities. It may be no more than the fact that in the United States the organized bar has a significantly deeper tradition of participation in law reform and less willingness to rely on government activity to produce reforms. The activities of the Council of State Governments in connection with interstate compacts, and the activities of other organizations interested in interstate compacts, would seem to indicate that wherever the participants are less representative of official government position, uniformity by agreement can be used just as easily as can voluntary action.

\section{III}

\section{The Future of the Natronal Conference}

If the reports of the presidents of the National Conference are indicative, the Conference has from an early time been puzzled by its lack of success in areas other than commercial law. ${ }^{17}$ Numerous presidential reports refer to the success of the Negotiable Instruments Act, the Warehouse Receipts Act, the Bills of Lading Act, the Stock Transfer Act, and-more recently-the Uniform Commercial Code, and to the lack of success of uniform laws proposed in the fields of marriage, divorce, workmen's compensation, and property. While the reports of the presidents of the

\footnotetext{
${ }^{17}$ See, e.g., I940 HANDBoOK 51-56; I962 HANDBooK 66.
} 
Conference have made little effort to carve out for the National Conference in relationship to Congress any area of substantive law which should be the province of the states, the presidential reports have attempted to analyze the reasons for the failure of some of the uniform acts during the seventy-five years of the history of the Conference. In the case of marriage and divorce, the reports have pointed out that there has been too much diversity of local custom among the states. It is interesting to note that the Hague Conference, of substantially the same age, has been equally unsuccessful in this field.

Sometimes the presidential reports refer to the failure of the Conference to act with sufficient speed as a reason for its lack of success in a particular area. The argument runs that when a problem arises in critical form, numerous states adopt legislation to solve it, and thereafter it is too difficult politically to induce these states to change to a uniform law. More recently, the risk in ability to act with speed has assumed significance in relation to federal legislation. Since the constitutional power of Congress is now understood to be exceedingly broad, any national problem can now speedily and uniformly be solved, by federal legislation. All too frequently, the demand for congressional legislation has proceeded too rapidly for the loosely organized Conference of Commissioners on Uniform State Laws to draft and secure the voluntary adoption of identical laws.

The procedure of the National Conference may well appear cumbersome. The tradition of the Conference has been to have uniform acts drafted by a Special Committee; and the Constitution of the Conference requires that a tentative draft be considered word by word by at least two annual meetings of the Conference sitting as Committee of the Whole. ${ }^{18}$ Thus, there is a minimum of three years from the time when the Committee on Scope and Program decides that the Conference should draft legislation in a particular area until the act is ready for enactment by the states. On the other hand, the advantage of this method, which admittedly appears cumbersome, is the seriousness of the deliberation and the carefulness of the drafting. The time interval permits the Special Committee of the National Conference to relate the solution of a particular problem more carefully to the comprehensive subject of which it is a part than does the procedure used frequently in legislative bodies to rush quickly to a solution of a narrow problem without regard to the impact of the solution on the general body of the law. The weakness of the Conference method seems not to arise so much from parliamentary procedure as from the fact that in its early stages, the drafting process is frequently divorced from consideration by participants in the legislative process in the state legislatures. Many times the Conference has drafted legislation without active participation by committees of the American Bar Association, and without the advice of the legal members of trade associations. The result has been that

${ }^{18}$ Constitution of the National Conference of Commissioners on Uniform State Laws, art. VIII(5), in 1964 HaNDBOOR 316. 
sometimes the National Conference has produced a solution to a problem which is impractical, but which could have been changed if expert advice had been sought early in the drafting process. Since the Uniform Commercial Code, where extensive use of advisory committees was made, the Conference has moved toward the appointment of expert advisers for most of its major subjects.

Some reports have seen the successes and failures of the Conference in terms of the demand for legislation by special interest organizations. ${ }^{19}$ These presidential reports have suggested that the Conference has been most successful where there was substantial demand for legislation before the Conference began to work. On first analysis, this suggested reason for success and failure would seem to be in conflict with the previously mentioned inability to operate speedily. Once the public has arrived at the "there ought to be a law" stage in its thinking about a problem, the Conference procedure may make it too late for the Conference to draft a uniform law. On further analysis, however, it would seem that what is here referred to is the fact that the Conference commenced operating at a time when organized groups in society were themselves beginning to consider the possibility of legislation, and that the Conference was successful in coordinating the initiative for legislation from the start. This appears to have been an important factor in the Uniform Commercial Code, since the Conference commenced drafting it at a time when various organizations interested in sales law were beginning to consider the possibility of preparing their own legislative proposals. Thus, it would seem that the Conference is most successful in the areas where it takes the initiative in drafting legislation substantially simultaneously with the manifestation of interest in legislation on the part of other groups in society.

This problem of timing the relationship of a "demand" for a uniform law and the procedure of the National Conference could, perhaps, be solved by more extensive use of another type of law drafting operation performed by the Conference. In the Ig20s, Professor Ernst Freund of the University of Chicago Law School, a Commissioner from Illinois, recommended that the Conference take charge of acts proposed by other organizations and properly draft and offer such acts to the state legislatures for adoption. ${ }^{20}$ He emphasized the service which the Conference could perform by bringing to bear its expert drafting experience on legislative proposals even where uniformity was not necessary. Professor Freund's proposal that the Conference take over acts drafted by other organizations does not meet the problem of timing, since the Conference procedure would have to be used after another organization had thought there was sufficient need for legislation to have produced a draft of its own. The proposal was rejected in the rg20s, but in 1936 the Constitution of the National Conference and the model state acts for appoint-

10 I962 HANDBOOK 66.

${ }^{20}$ I920 HANDBDOK 63 . 
ment of Commissioners were amended to permit the Conference to draft "model" acts as well as "uniform" acts. ${ }^{21}$

The distinction between a model act and a uniform act is a slight one, and lies primarily in the difference of the duties of the Commissioners as regards these two types of acts. If the Conference has promulgated a uniform act, the Commissioners from each of the states are obligated to attempt to secure passage of the uniform act in their state legislatures in an unamended form. With respect to model acts, on the other hand, the Commissioners from each of the states have no duty other than supplying copies of the various acts to interested organizations in their own states upon request. While the Conference has made use of its model act procedure since this became permissible, it has done so initially in only two general areas: It has sometimes reduced to the "model act" category some uniform acts which were relatively unsuccessful; and it has drafted model acts in areas where the Committee on Scope and Program thought that there was no substantial "necessity" for uniformity, although uniformity might be desirable. Taking the initiative in model acts presents a difficult competitive problem for the Conference. Numerous organizations, both public and self-interest, draft model acts for the use of state legislatures in search of solutions to particular problems; and it is questionable whether the Conference has any special or unique expertise to offer here. Nevertheless, model acts could serve an important function in the operation of the National Conference. If the Conference could foresee that there would be a probable demand for legislation on the subject, and a need for uniform legislation, it could draft model acts and promulgate them as such. Thereafter, whenever the intensive demand which seems to be so important for the success of uniform acts. arises, the Conference could change the classification of the model act to that of a. uniform act, perhaps amending it at that time. This would permit the timeconsuming operations of the Conference to take place before the serious necessity for a uniform act is foreseen or pressing.

\section{Conclusion}

Now that Congress has legislative power in almost all of the areas where uniformity of state law was originally conceived of as "necessary," and now that there are numerous organizations-bar associations, special purpose public interest 'groups, special purpose self-interest groups, and other law reform agencies, both public and private-busily drafting legislation to improve the law, the role of the National Conference has substantially changed. That the organization is not dead can be seen from the success that it has had with the Uniform Commercial Code, its most ambitious project in its entire history. This.uniform law, which puts together all the uniform laws drafted in earlier eras concerning commercial subjects, has now

\footnotetext{
${ }^{21}$ I936 HANDBOOK II8.
} 
been adopted by more than eighty per cent of the states, and the prospect of complete uniformity by voluntary state action is high. The history of the Code would suggest that comprehensiveness may be an important criterion for future activity of the Conference. "Necessity" alone no longer appears sufficient, for if uniformity on a particular problem is substantially necessary, the modern tendency of seeking federal legislation reduces the strength of the National Conference-at least if it does not commence the drafting process until after the demand or the necessity arises. It would appear that if it will not only exercise foresight in the sense of discovering particular areas likely to call for legislative solution, but will then proceed to draft a comprehensive law covering the whole subject matter including the area where there seems to be a demand for uniformity, the Conference still has a substantial role to perform.

A current subject on the Conference agenda may be illustrative of the places where the Conference could have success in the future. By hindsight it is possible to say that in the field of consumer credit, which the Conference deliberately omitted from the Uniform Commercial Code, there are some problems demanding solution. Thus, there is considerable demand for uniform legislation by congressional direction concerning the method of disclosing the cost of credit to the consuming public. The proposals for federal legislation, however, are narrowly limited to this one aspect of consumer credit. The Conference has now undertaken the drafting of comprehensive uniform legislation covering the entire subject of consumer credit from advertising through contractual disclosure of the finance charge to the collection process. The literature would indicate that there are many aspects of the field of consumer credit where there is a growing demand and necessity for uniformity. It appears that if the Conference is successful in obtaining uniformity for this subject by voluntary state action rather than by congressional direction, this will be so because it has looked at the current specific problems as part of a larger comprehensive subject in the same way that the particular demand for reform in certain aspects of sales law was regarded as part of a more comprehensive commercial code.

For the consumer credit project, the Conference was slow in exercising foresight as to the need for reform. Its future will lie, it is believed, primarily in its ability to act with foresight in discovering particular areas likely to involve legislative problems, and in relating the specific problem to a more comprehensive mould, and having a draft ready for state adoption of a comprehensive act almost simultaneously with the discovery by some groups (or by Congress) that there is a narrow problem which needs solution. There is no doubt that this can be done, and that we can continue to solve problems by state action which have conventionally been left to the states even though there is congressional power, if the Conference and the state leadership have the will to do so. 
This brief account of the history of the Commissioners on Uniform State Laws is not the place to make what is perhaps the most significant analysis of the successes and failures of the Conference. A case can certainly be made that the real indicia of Conference success and failure is the total commitment of a few Commissioners to the principle of uniformity and to the subject matter of particular acts. Without such total commitment very few significant reforms and advances occur anywhere in our society, and the National Conference should, if the analysis is made, be no exception to this rule. To take a concrete illustration, would more than eighty per cent of the states have adopted the Uniform Commerical Code by 1965 without the total commitment of Commissioner Schnader to the Code and to its adoption? 